\title{
Changes in Nucleic Acid and Protein Content of the Human Brain During Growth
}

\author{
MYRON WINIGK ${ }^{[16]}$ \\ Department of Pediatrics, Cornell Medical Center, New York, New York, USA
}

Extract

In order to establish the pattern of cellular growth, nucleic acid and protein content were serially determined in 31 human brains. The earliest material was obtained from a fetus with a gestational age of 13 weeks; the latest from a 13-month-old infant. Weight protein, and RNA content increased linearly during this period. Weight increased from $5 \mathrm{~g}$ to $970 \mathrm{~g}$, protein from $193 \mathrm{mg}$ to $53 \mathrm{~g}$, and RNA from 18.5 to $1384 \mathrm{mg}$. In contrast, increase in DNA content began to level off at about the time of birth and reached a maximum (approximately $900 \mathrm{mg}$ ) by five months of age. These data indicate that very little cell division occurs in the human brain after five months of age and that further growth occurs by increase in protein, RNA and, perhaps, lipid content of cells.

\section{Speculation}

The findings in this study indicate that cell division in the human brain appears to continue until five months of age and ceases thereafter. Further growth is by increase in protein, RNA and lipid content per cell. Data obtained from animals indicate that the brain is most sensitive to certain stimuli during the period of active cell division. In the human, cell division occurs during all of prenatal life and the first five months of postnatal life. It is possible that adverse environmental factors such as malnutrition and anoxia may be most deleterious during this period.

\section{Introduction}

Since DNA content per diploid cell is constant for any species [1], the quantity of DNA in an organ at any time reflects the number of cells present at that time. In the growing rat, cell division stops in most organs before the organ attains its final size [11]. In the rat brain, DNA content reaches a maximum at about 17 days after birth $[6,11]$. In the mouse brain, the maximum is achieved at 14 days of age [7], while in the guinea pig brain, there is little increase in DNA content of the brain after birth [7]. The only human organ which has been serially studied is the placenta. Although the human placenta increases in weight and total protein content until term, the amount of DNA ceases to increase after the 35th week of gestation [10]. Thus in the one human organ studied, cell division also stops before growth ceases. Data on other human organs are incomplete. In the brain, there are indications that by one year of age, DNA content may have reached a maximum [6]; however, in this study, few measurements were made and these only at birth and at one year of age. Hence the sequential change in DNA content of the human brain has not been determined. The present study provides these data.

\section{Materials and Methods}

Thirty-one human brains were examined. They were derived from patients dying suddenly in cribs, from children who died in accidents or from acute poisoning, 
and from fetuses secured when therapeutic abortions were performed for psychiatric reasons. Brains were collected from fetuses with a gestational age as young as 13 weeks. The oldest specimen studied was a child who died at 13 months of age.

Analyses were performed for organ content of DNA, RNA, and protein. The methods employed for analyses have been previously described [11, 13]. Preparatory experiments in the rat brain and the human placenta have indicated no loss in DNA content and less than $5 \%$ loss in protein and RNA content within the first hour after death and parturition respectively; therefore, only brains secured within one hour after death were used. These were homogenized in toto to a $20 \%$ suspension in distilled water. DNA, RNA, and protein were separated by a modification of the Schmidt-Thannhauser procedure [8]. Incorporation and recovery studies previously performed using rat brains showed that the methods used were effective for fractionation of these components of the central nervous system. DNA was determined by Burton's modification of the diphenylamine reaction [2]. When verified by direct ultraviolet spectrophotometry, there was agreement between the methods within $5 \%$. RNA was determined by the orcinol reaction [4] and protein by the method of LowRY et al. [5].

$$
\text { Results (table I) }
$$

Total brain weight increased linearly from 13 weeks of gestation until 13 months of age. At 13 weeks of gestation, the average brain weight was $5 \mathrm{~g}$; at 13 months, it had reached $970 \mathrm{~g}$ (fig. 1).

The increase in weight was accompanied by a linear rise in total protein content. During the growth period studied, total brain protein increased from $193 \mathrm{mg}$ to $53 \mathrm{~g}$ (fig. 2).

RNA content also increased chronologically in a linear fashion from $18.5 \mathrm{mg}$ to $1384 \mathrm{mg}$ (fig. 3). Thus, weight, protein, and RNA all showed similar patterns of increase throughout the period of life under examination.

In contrast, although DNA content rose in linear fashion from a value of $25.4 \mathrm{mg}$ at 13 weeks of gestation to one of $600 \mathrm{mg}$ at birth, thereafter the slope of increase began to level off. There was a decelerating increase following birth until a maximum content was reached by about 5 months of age (fig. 4 ).

\section{Discussion}

The sequence of cellular changes during the growth of human brain is qualitatively similar to that seen in the rat brain; i.e., DNA reaches a maximum content after birth but prior to the cessation of total brain growth. The latter part of growth is characterized by an increase in total organ weight and protein, as well as RNA content without concomitant increases in DNA content. During this phase ( 5 months until at least 13 months of age), there is a rapid increase in the ratio of protein and RNA to DNA. These data indicate an increase in the quantity of protein and RNA per cell.

Cell division in rat brain may be retarded during the period of active DNA synthesis by certain adverse circumstances such as caloric restriction. Growth under these conditions produces a brain with a reduced num-

Table I.

\begin{tabular}{lcccl}
\hline Age & $\begin{array}{l}\text { Weight } \\
(\mathrm{g})\end{array}$ & $\begin{array}{l}\text { Protein } \\
(\mathrm{g})\end{array}$ & $\begin{array}{l}\text { RNA } \\
(\mathrm{mg})\end{array}$ & $\begin{array}{l}\text { DNA } \\
(\mathrm{mg})\end{array}$ \\
\hline $\begin{array}{l}\text { Weeks of } \\
\text { gestation }\end{array}$ & & & & \\
13 & 5 & 0.193 & 18.5 & 25.4 \\
17 & 24 & 0.6 & 55 & 85 \\
21 & 47 & 1.56 & 100 & 78 \\
23 & 60 & 2.73 & 150 & 134 \\
25 & 85 & 4.68 & 200 & 251 \\
27 & 100 & 5.78 & 190 & 240 \\
30 & 90 & 5.0 & 190 & 198 \\
31 & 130 & 6.56 & 220 & 285 \\
33 & 200 & 9.22 & 300 & 385 \\
38 & 275 & 15.6 & 420 & 620 \\
40 & 286 & 15.8 & 415 & 634 \\
40 & 350 & 16.56 & 460 & 685
\end{tabular}

Months after birth

\begin{tabular}{lrlrr}
$1 / 2$ & 375 & 17.34 & 460 & 690 \\
1 & 365 & 20.0 & 530 & 785 \\
$21 / 2$ & 417 & 22.2 & 675 & 817 \\
3 & 426 & 23.9 & 700 & 790 \\
3 & 383 & 25.78 & 750 & 858 \\
$31 / 2$ & 417 & 25.0 & 780 & 885 \\
4 & 434 & 27.34 & 800 & 825 \\
$41 / 2$ & 468 & 25.78 & 820 & 851 \\
5 & 534 & 28.9 & 850 & 900 \\
5 & 542 & 30.0 & 800 & 917 \\
$61 / 2$ & 680 & 37.34 & 1020 & 900 \\
7 & 651 & 35.8 & 1000 & 880 \\
10 & 800 & 45.0 & 1150 & 861 \\
10 & 851 & 45.8 & 1180 & 890 \\
$101 / 2$ & 851 & 47.34 & 1240 & 968 \\
$11 \frac{1}{2}$ & 900 & 49.68 & 1285 & 934 \\
$11 \frac{1}{2}$ & 934 & 51.56 & 1350 & 968 \\
12 & 942 & 52.34 & 1368 & 1000 \\
$12 \frac{1}{2}$ & 970 & 53.90 & 1384 & 940 \\
\hline
\end{tabular}




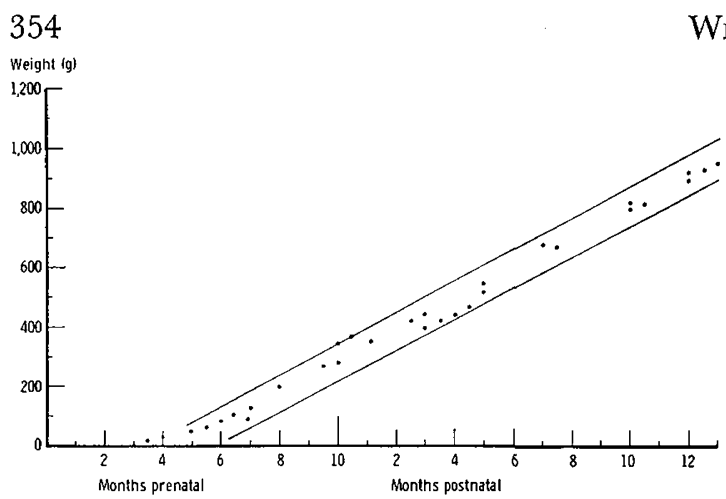

Fig. 1. Each point represents a single brain.

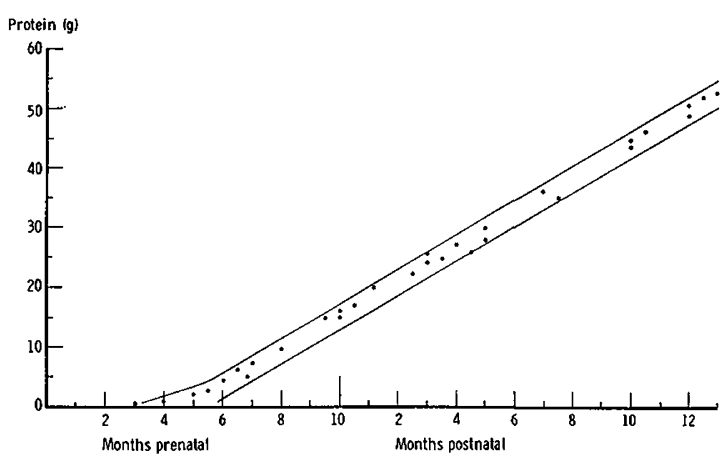

Fig. 2. Each point represents a single brain.

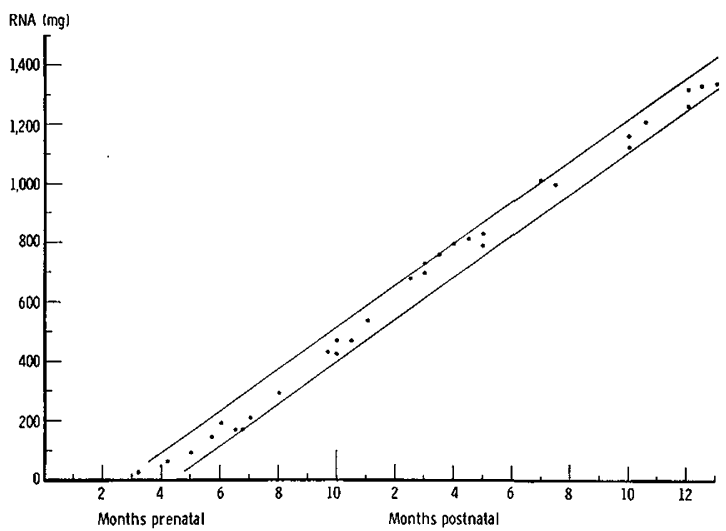

Fig. 3. Each point represents a single brain.

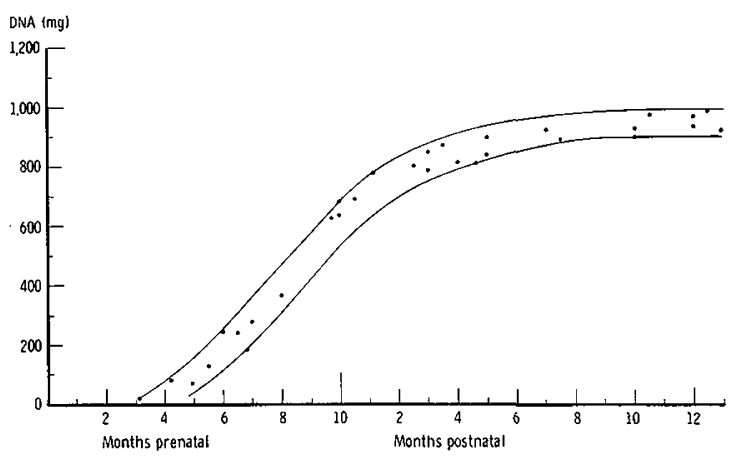

Fig.4. Each point represents a single brain.
WINICK

ber of cells. When the same conditions exist later in life, that is, after cell division has stopped, there is no effect upon the number of cells in the organ [12]. Cell division in the human placenta [10] can also be retarded by inanition during the period of most active proliferation, and the same observation pertains to muscle [3]. Therefore, a knowledge of the time at which total DNA content of the human brain reaches a maximum might be important for establishing the critical time during which the human brain might be most susceptible to the growth-retarding effects of malnutrition.

These data set the time of active cell division for the human brain from before 13 weeks of gestation until about 5 months of age. DNA content increases rapidly in a linear fashion until birth and then increases at a decelerating rate to 5 months of age. Thereafter, brain growth is accomplished without further cell division and results from an increase in the cellular content of protein, RNA, and, perhaps, lipid.

\section{Summary}

Weight, protein, and RNA increase linearly in the human brain between 13 weeks of gestation and 13 months of age. DNA content, however, rises rapidly until birth and then more slowly until five months of age, when it reaches a maximum. Therefore, growth after five months of age in the human brain is accomplished without apparent cell division.

\section{References and Notes}

1. Botvin, A.; Vendrely, R. et Vendrely, G.: L'acide desoxyribonucléique du noyau cellulaire, dépositaire des caractères héréditaires; arguments d'ordre analytique.C. R. Acad. Sci.226:1061 (1948).

2. Burton, K.: A study of the conditions and mechanisms of the diphenylamine reaction for the colorimetric estimation of desoxyribonucleic acid. Biochem.J. 62: 315 (1956).

3. Gheek, D.B.; Graystone, J. and Mehrizi, A.: The importance of muscle cell number in children with congenital heart disease. Bull.Johns Hopk. Hosp. 118: 140 (1966).

4. Dische, A.: in: The nucleic acids (ed. Ghargaff, E. and Davidson, J.N.), vol. 1 (Academic Press, New York 1955).

5. Lowry, O.H.; Rosebrough, N.J.; FaAr, H.L. and Randall, R.J.: Protein measurement with the folin phenol reagent. J.biol. Chem. 193: 265 (1951).

6. Mandel, P.; Beith, R. and Weill, J. D.: in: Metabolism of the nervous system (ed. Richter, D.), p. 291 (Pergamon Press, London 1957). 
7. MANDEL, P.; ReIn, H.; HAK íH-Edel, S. and MARDELL, R.: in: Comparative neurochemistry (ed. Richter, D.), p. 153 (Pergamon Press, London 1964).

8. Schmidt, G. and Thannhauser, S.J.: A method for the determination of desoxyribonucleic acid, ribonucleic acid and phosphoproteins in animal tissues. J. biol. Ghem. 161: 83 (1945).

9. Winick, M.: Cellular growth of human placenta. III. Intrauterine growth failure. J.Pediat. 71: 390 (1967).

10. Winick, M.; Goscia, A. and Noble, A.: Cellular growth in human placenta. I. Normal placental growth. Pediatrics 39: 248 (1967).

11. Wriciak, M. and Noble, A.: Quantitative changes in DNA, RNA, and protein during prenatal and postnatal growth in rat. Develop. Biol. 12: 451 (1965).
12. Winick, M. and Noble, A.: Cellular response in rats during malnutrition at various ages. J. Nutr. 89: 300 (1966).

13. Winick, M. and Noble, A.: Quantitative changes in ribonucleic acids and protein during normal growth of rat placenta. Nature (Lond.) 212: 34 (1966).

14. This research was supported by the National Foundation Grant 1270, the Nutrition Foundation Grant 357, and the New York Gity Health Research Council Contract U1769.

15. The author wishes to acknowledge the aid of Dr. FRITZ FuCHS and the Departments of Obstetrics and Pathology for helping collect most of the material.

16. Requests for reprints should be addressed to Myron Winiak, M.D., The New York Hospital, 525 East Sixty-Eighth Street, New York, N.Y. 10021 (USA). 